\title{
Reach-scale river dynamics moderate the impact of rapid Holocene climate change on floodwater farming in the desert Nile
}

\author{
Mark G. Macklin ${ }^{1 *}$, Jamie C. Woodward ${ }^{2 *}$, Derek A. Welsby ${ }^{3}$, Geoff A.T. Duller ${ }^{1}$, Frances M. Williams ${ }^{4}$, and \\ Martin A.J. Williams ${ }^{5}$ \\ IInstitute of Geography and Earth Sciences, Aberystwyth University, Aberystwyth SY23 3DB, UK \\ ${ }^{2}$ School of Environment and Development, The University of Manchester, Manchester M13 9PL, UK \\ ${ }^{3}$ Department of Ancient Egypt and Sudan, the British Museum, London WC1B 3DG, UK \\ ${ }^{4}$ School of Chemistry and Physics, University of Adelaide, Adelaide, SA 5005, Australia \\ ${ }^{5}$ Department of Geography, Environment and Population, University of Adelaide, Adelaide, SA 5005, Australia
}

\begin{abstract}
The relationship between climate change and the development of Old World riverine civilizations is poorly understood because inadequate dating control has hindered effective integration of archaeological, fluvial, and climate records. This paper presents the most comprehensive and robustly dated archaeological and paleoenvironmental data sets yet compiled for the desert Nile. It focuses on the valley floor hinterland of the Kingdom of Kerma (2400-1450 B.C.) in northern Sudan. Kerma emerged as a rival to Egypt during Africa's first "Dark Age" drought. In contrast to other irrigation-based agriculturists in Egypt and Asia, Kerma flourished during the environmental crisis ca. 2200 B.C. We have studied the stratigraphy and archaeological records of paleochannels across an $80 \mathrm{~km}$ reach of the Nile upstream of Kerma using optically stimulated luminescence to date when channels flowed and when they dried up. The dynamics of the local alluvial environment were critical in determining whether climatic fluctuations and changes in river flow represented an opportunity for floodwater farmers (5000-3500 B.C.), a hazard that could be managed (2400-1300 B.C.), or an environmental catastrophe that resulted in settlement abandonment (after 1300 B.C.).
\end{abstract}

(Fig. 1A) (Bonnet, 1992; Welsby et al., 2002). With monumental architecture and elaborate fortifications, Kerma emerged as a powerful independent polity by controlling trade on the Nile. The metropolis at Kerma was supported by a fertile hinterland with anabranching channels ideally suited to irrigation-based agriculture and livestock rearing (Welsby et al., 2002). During the Kerma period, the eastern side of the Nile Valley from Mulwad to the Third Cataract (Fig. 1A), a distance of $135 \mathrm{~km}$, was especially favorable for settlement and farming.

\section{STUDY AREA AND METHODS}

The $80 \mathrm{~km}$ study reach is located to the south of Kerma in the hyperarid Nubian Desert, and

\section{INTRODUCTION}

Climatically driven changes in river flow are of critical importance for floodwater farming in exotic rivers such as the desert Nile. However, the relationship between rapid climate change and the development of Old World riverine civilizations is poorly understood, primarily because of inadequate dating control and limited integration of archaeological, fluvial, and climate records. The Nile's flow regime integrates two parts of the global climate system: the summer monsoon in the Northern Hemisphere and equatorial rainfall in the Intertropical Convergence Zone. Changes in the flux of water and sediment to the desert Nile are controlled largely by climate in the Blue Nile-Atbara and White Nile basins (Woodward et al., 2007). The fluvial and archaeological records of northern Sudan have allowed us to explore the interactions between Holocene climate change, river dynamics, and human activity in unusual detail. A key aim is to shed new light on the history of the desert Nile and its people in the context of the ongoing debate about societal collapse and Holocene environmental change (Weiss et al., 1993; Stanley et al., 2003).

\section{KINGDOM OF KERMA}

Between 2400 and 1450 B.C., a remarkable Bronze Age kingdom dominated the Nile Valley between the Second and Fourth Cataracts

*E-mails: mvm@aber.ac.uk; jamie.woodward@ manchester.ac.uk.
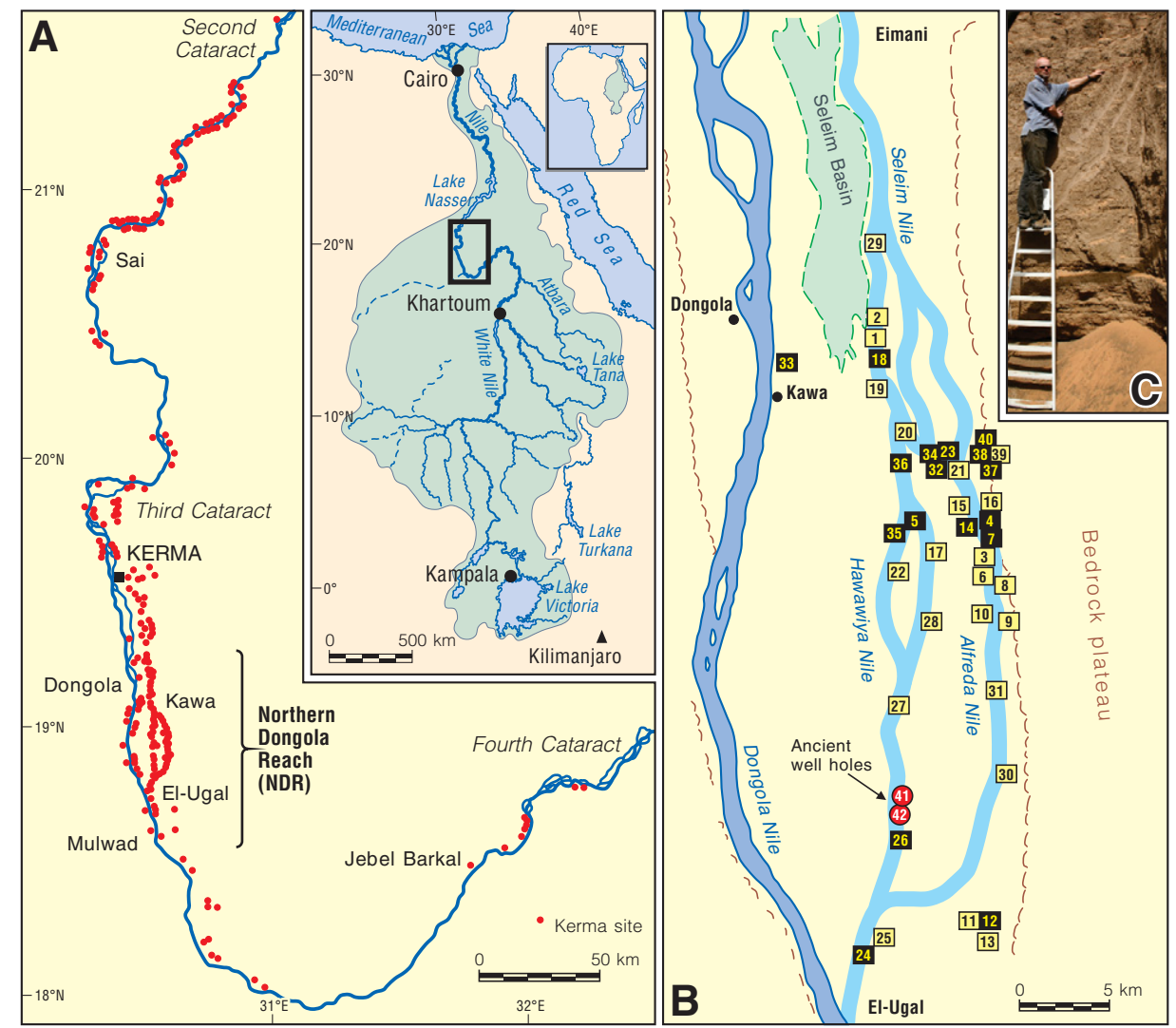

Figure 1. A: Kerma sites between the Second and Fourth Cataracts of the Nile. Inset: Nile basin. B: Exposures in the Northern Dongola Reach (NDR) where the Holocene stratigraphy has been recorded. Sites shown in black and red were dated by optically stimulated luminescence (OSL) or ${ }^{14} \mathrm{C}$. C: Well pit section (site 40 ). 
includes the modern town of Dongola $\left(19^{\circ} 10^{\prime} \mathrm{N}\right)$. The Northern Dongola Reach (NDR) (Fig. 1A) is bordered by a bedrock plateau to the east and by the modern Dongola Nile to the west (Fig. 1B). Archaeological survey of the NDR has discovered more than 450 sites spanning the Neolithic (pre-3500 B.C.) to the Medieval Christian period (A.D. 500-1500). Many sites are associated with a well-preserved system of paleochannels. Ground-based surveys and satellite images were used to delineate former channel belts and establish their relationship to these sites. Thousands of potsherds provide dating control for these sites. Investigation of the Holocene geological record has been facilitated by the many hundreds of pits in the NDR dug by modern farmers to house diesel pumps for groundwater-fed irrigation (Woodward et al., 2001). These provide three-dimensional exposures along all the paleochannel belts, and 40 locations have been logged (Figs. 1B and 1C). We have also studied paleochannel fills and eolian sediments filling ancient well shafts. Across 19 locations, 33 sedimentary units (including fluvial and eolian sands) have been dated by optically stimulated luminescence (OSL) (see the GSA Data Repository'1), and charcoal associated with in-situ archaeological features has been ${ }^{14} \mathrm{C}$ dated.

\section{ARCHAEOLOGY OF THE NDR PALEOCHANNELS}

Three major paleochannel systems (Hawawiya, Alfreda, and Seleim), between 1 and $3 \mathrm{~km}$ wide, have been mapped to $18 \mathrm{~km}$ east of the modern Dongola Nile (Fig. 1B). Individual anabranches are convex in cross section with levees $\sim 2 \mathrm{~m}$ above the valley floor. Preservation of the archaeological record is good: sites ranging from Neolithic to post-Kerma are found in close association at the modern land surface. Site burial by fluvial sedimentation is limited because most are found on levees along the channel margins and the location of the main channel belts has not changed appreciably over the past 8000 yr. Integration of the archaeological and geological data sets in the NDR shows when channels conveyed flows (and could be used for agriculture) and when they dried out and were abandoned (Fig. 2).

\section{Neolithic Period (5000 to 3500 B.C.)}

Neolithic sites are widely distributed across the valley floor, reflecting more humid climatic conditions (Ritchie et al., 1985; Kuper and Kröpelin, 2006), higher river flows, and a more extensive channel network at that time (Williams et al., 2000) (Fig. 2A). OSL dating of fluvial sands shows that the Dongola Nile (ca. 4000 B.C.), the Alfreda and Seleim (62003700 B.C.), and the Hawawiya (5500-5100 B.C.) paleochannel belts were all active (Fig. 3). Operating together, these would have significantly increased the amount of land available for seluka cultivation (the cultivation of land between the high and low flow stages) without the need for irrigation (Welsby et al., 2002).

\section{Kerma Period (2400 to 1450 B.C.)}

With the emergence of the Kerma culture ca. 2400 B.C., the number and location of permanent settlements in the NDR changed radically. As the channel network contracted, there was a shift of sites to the Alfreda and Seleim channels (Fig. 2B). Three cultural phases have been recognized during Kerma times (Fig. 3) (Bonnet, 1992). Kerma Ancien (2400-2050 B.C.) sites are found in similar numbers along the three channel belts, but in the Kerma Moyen (2050-1750 B.C.) and in the Kerma Classique (1750-1450 B.C.) periods, the number of settlements associated with the Alfreda and Seleim Nile channel belts more than doubled from 40 to 90 (Fig. 3). By contrast, along the Hawawiya Nile, the number of settlements decreased in Kerma Classique times; no sites later than ca. 1450 B.C. are recorded (Fig. 3). This major
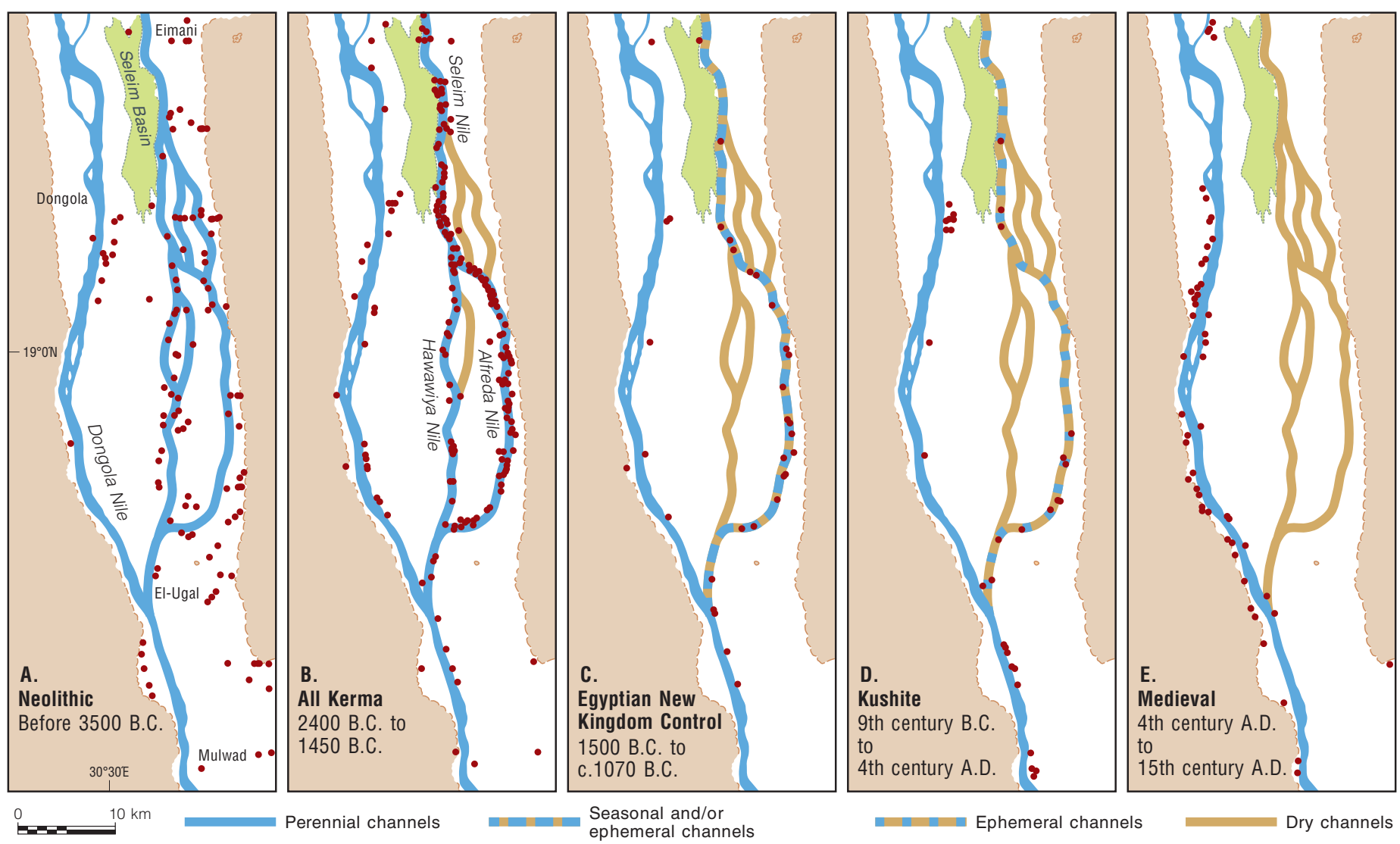

Figure 2. Neolithic to Medieval archaeology (red dots) and channel dynamics in the Northern Dongola Reach.

${ }^{1}$ GSA Data Repository item 2013190, OSL methods and data and radiocarbon data for the Northern Dongola Reach, is available online at www.geosociety.org/pubs /ft2013.htm, or on request from editing@ geosociety.org or Documents Secretary, GSA, P.O. Box 9140, Boulder, CO 80301, USA. 

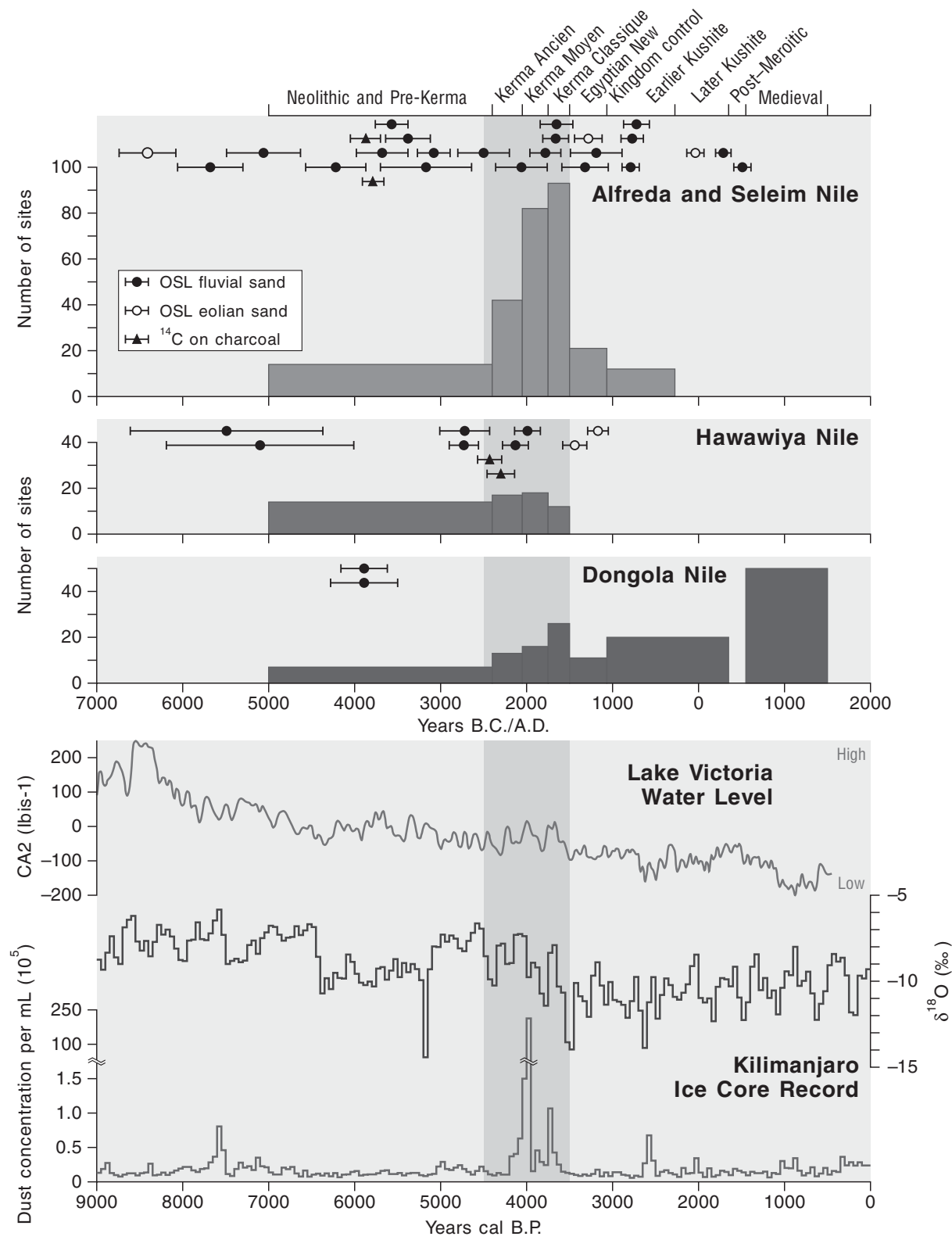

Figure 3. Integration of archaeological data with dated phases of fluvial and eolian sand deposition in the Northern Dongola Reach and regional paleoclimate records (OSL-optically stimulated luminescence). Bars show number of archaeological sites recorded for each channel system for each period. Lower diagram shows proxy climate records from the Kilimanjaro ice core record (Thompson et al., 2002) close to the White Nile headwaters (see Fig. 1) (cal B.P.-calendar years before present). Proxy for the White Nile flows is also shown from correspondence analysis of diatom data from core (Ibis-1 core, axis CA2) in the Damba Channel of Lake Victoria (Stager et al., 2003). Central shaded bar shows African "Dark Age" when drying climate produced high dust concentrations in the region.

change in settlement pattern coincides with the drying of the Hawawiya Nile channel belt ca. 1990 B.C. $( \pm 150 \mathrm{yr})$. This corresponds with the well-documented climate event ca. 2200 B.C., which caused reduced river flow in the lower Nile and is believed to have been a key influence on the demise of the Egyptian Old Kingdom (Bell, 1971; Hassan, 1997; Stanley et al., 2003). In the NDR, however, Kerma communities were remarkably resilient to this episode of rapid environmental change and regional drought. Kerma sites increased significantly in this period and shifted from the western and central parts of the NDR to the easternmost edge of the valley floor, becoming concentrated on levees along the Alfreda and Seleim channels of the Nile (Figs. 2 and 3).

\section{END OF THE KERMA PERIOD}

After ca. 1450 B.C. there was a further dramatic change in settlement number and location; during this period there was a total abandonment of sites in the Hawawiya Nile channel belt (Fig. 2C) and a marked reduction in the number of settlements in the Alfreda-Seleim (from 90 to 21) and Dongola (from 23 to 10) systems (Fig. 3). Eolian sands infilling two ancient bricklined wells sunk (sites 41 and 42 in Fig. 1B) into the former bed of the Hawawiya Nile channel have been dated to 1170 B.C. $( \pm 120 \mathrm{yr})$ and 1440 B.C. $( \pm 140 \mathrm{yr})$, respectively. These provide a limiting age for the presence of flowing water in this system (Fig. 3).

\section{High-Resolution Record of Nile Floods}

Declining flood flows and the drying out of the Alfreda Nile are recorded very precisely $\sim 2 \mathrm{~km}$ upstream from its confluence with the Hawawiya Nile channel belt. A 2.3-m-deep section (pit 32) in the center of an Alfreda paleochannel preserves a sequence of silty Nile flood units interbedded with eolian sands (Fig. 4). OSL dating of eolian sands at the bottom of the exposure shows that this channel belt first dried up completely shortly before 1290 B.C. $( \pm 160 \mathrm{yr})$. This is confirmed by OSL ages on an adjacent levee $250 \mathrm{~m}$ from the mid-channel pit showing that floodplain sedimentation continued in this reach to ca. 1320 B.C. $( \pm 270 \mathrm{yr})$ (pit 34; Tables DR1 and DR2 in the Data Repository). These ages indicate a sudden failure of this system, perhaps in less than a century, but error terms in the OSL ages preclude a more precise estimate. An event of this kind would have been catastrophic for floodwater farming and explains the permanent abandonment of large parts of the NDR at the time. After 1290 B.C., the Alfreda Nile carried flows for a short period between ca. 780 B.C. $( \pm 130 \mathrm{yr})$ and 730 B.C. $( \pm 150 \mathrm{yr})$ (Fig. $2 \mathrm{D})$. Both historical and OSL-dated sedimentological evidence (Fig. 4) identify a period of unusually large Nile floods during the early Kushite period in the NDR. Later episodes of flooding are recorded ca. 45 B.C. $( \pm 100 \mathrm{yr})$ and A.D. 280 ( $\pm 90 \mathrm{yr}$ ), which was the last time the Alfreda channel was active. All major settlements have been located on the modern Dongola Nile since the $4^{\text {th }}$ century A.D. (Fig. 2E).

\section{RAPID CLIMATE CHANGE AND RIVER DYNAMICS}

Our results show that the nature and dynamics of local alluvial environments were critical factors in determining whether climatic fluctuations and associated changes in river flow represented an opportunity for floodwater farmers, a hazard that could be managed, or an environmental catastrophe that forced the abandonment of previously fertile land that had supported a large Kerma population for 1000 yr. Major alterations in settlement patterns and, by inference, floodwater farming practices between the Neolithic, Kerma, Kushite, and Medieval periods can be related to differences in rates and styles of channel and floodplain sedimentation, the number of channel anabranches, and to climatedriven changes in river discharge. As the Kerma 

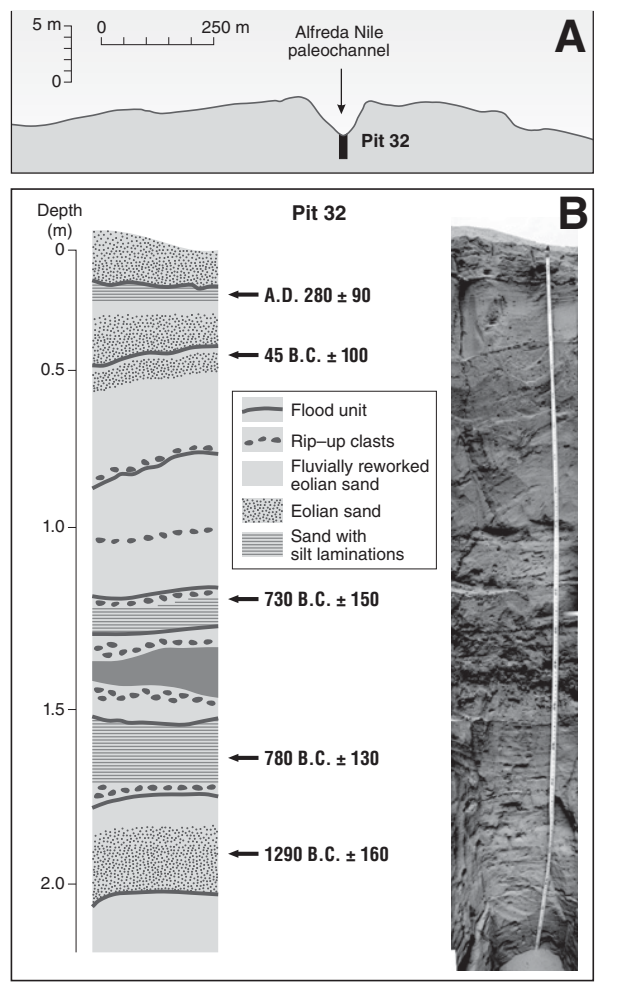

Figure 4. A: Channel cross section within the Alfreda Nile paleochannel belt, showing the context of pit 32. B: Schematic of Nile flood records from the paleochannel fill at pit 32 (left) and a photograph of the same postKerma flood units and eolian sands.

civilization developed, sites became concentrated within a narrowing zone along the three anabranching channel belts in the NDR. Kerma rose to prominence during Africa's first "Dark Age" (brought about by drought at ca. 2200 B.C.), but, unlike other irrigation-based agriculturists in Egypt and Asia, it flourished during the environmental crisis associated with the ca. 2200 B.C. drought. This may reflect greater reliance on animal husbandry practices that are less susceptible to changes in flood level, more mobile, and better able to cope with environmental stress. However, the continuity of the Kerma agriculturists appears to have arisen from a combination of local geomorphological and hydrological factors: (1) an anabranching river system with channel-side accretion creating levee-belt topography ideally suited for floodwater farming, and (2) a period of intermediate-sized Nile floods that in the NDR were large enough to support at least seasonal flows and farming in the Alfreda channel belt, but not so big as to cause damage to channelside settlements. Farming in the NDR may have been aided by a period of enhanced White Nile flows during the Kerma period (Fig. 3; Stager et al., 2003). The end of the Kerma civilization was precipitated initially by the invasion of the region by Eighteenth Dynasty Egypt (ca. 1500 B.C.), followed by the drying out of the Alfreda and Seleim channel belts in the NDR no later than ca. 1320-1290 B.C. This severe reduction in Nile flow appears to be unmatched in the period 3500 to 1500 B.C. It coincided with the abrupt and permanent ${ }^{18} \mathrm{O}$ depletion in the Kilimanjaro ice core record ca. 1450 B.C. (Fig. 3; Thompson et al., 2002) that marks the shift to the hyperarid climate across this part of Africa that persists to the present day (Kuper and Kröpelin, 2006). The distribution of Kerma sites downstream shows that the failure of the Alfreda and Seleim paleochannels would have had a devastating impact as far as the Third Cataract (Fig. 1A).

\section{CONCLUSIONS}

Major disruptions to floodwater farming communities during the Bronze Age in northern Sudan were climatically induced. They were not associated with the ca. 2200 B.C. drought that has been linked to the collapse of the Akkadian Empire (Weiss et al., 1993) and early civilizations in Egypt (Stanley et al., 2003) and the Indus Valley of Pakistan (Staubwasser et al., 2003). They occurred nearly $1000 \mathrm{yr}$ later as the result of an abrupt $(<100 \mathrm{yr})$ climate-related failure of a major ( $>100-\mathrm{km}$-long) channel belt, the flow of which had supported floodwater farming in the region since the Neolithic. Channel and floodplain dynamics in the NDR significantly moderated the local impact of rapid climate change on patterns of flood inundation. The persistence of a favorable channel and floodplain topography in the NDR was critically important for sustaining floodwater farming in this part of the desert Nile and perhaps more widely in similar dryland river civilizations in both the Old and New Worlds.

\section{ACKNOWLEDGMENTS}

Field work was supported by the Sudan Archaeological Research Society, the British Museum, and Australian Research Council grant ARC DP0878058. We thank Isabella Welsby-Sjöström (ceramics), Nick Scarle (diagrams), and John Lewin, Gary Huckleberry, Michael Staubwasser, and two anonymous reviewers for very helpful comments.

\section{REFERENCES CITED}

Bell, B., 1971, The Dark Ages in ancient history: The first dark age in Egypt: American Journal of Archaeology, v. 75, p. 1-25, doi:10.2307/503678.

Bonnet, C., 1992, Excavations at the Nubian royal town of Kerma: 1975-91: Antiquity, v. 66, p. 611-626.

Hassan, F.A., 1997, Nile floods and political disorder in early Egypt, in Dalfes, N., et al., eds., Third millennium BC climate change and old world collapse: NATO ASI Series I 49, p. 1-24.

Kuper, R., and Kröpelin, S., 2006, Climate-controlled Holocene occupation of the Sahara: Motor of Africa's evolution: Science, v. 313, p. 803-807, doi:10.1126/science.1130989.

Ritchie, J.C., Eyles, C.H., and Haynes, C.V., 1985, Sediment and pollen evidence for an early to midHolocene humid period in the eastern Sahara: Nature, v. 314, p. 352-355, doi:10.1038/314352a0.

Stager, J.C., Cumming, B.F., and Meeker, L.D., 2003, A 10,000-year high-resolution diatom record from Pilkington Bay, Lake Victoria, East Africa: Quaternary Research, v. 59, p. 172181, doi:10.1016/S0033-5894(03)00008-5.

Stanley, J.-D., Krom, M.D., Cliff, R.A., and Woodward, J.C., 2003, Nile flow failure at the end of the Old Kingdom: Strontium isotopic and petrologic evidence: Geoarchaeology, v. 18, p. 395 402, doi:10.1002/gea.10065.

Staubwasser, M.F., Sirocko, F., Grootes, P.M., and Segl, M., 2003, Climate change at the $4.2 \mathrm{ka}$ BP termination of the Indus Valley civilization and Holocene south Asian monsoon variability: Geophysical Research Letters, v. 30, 1425, doi:10.1029/2002GL016822.

Thompson, L.G., Mosley-Thompson, E., Davis, M.E., Henderson, K.A., Brecher, H.H., Zagorodnov, V.S., Mashiotta, T.A., Ping-Nan Lin, Mikhalenko, V.N., Hardy, D.R., and Beer, J., 2002, Kilimanjaro ice core records: Evidence of Holocene climate change in tropical Africa: Science, v. 298, p. 589-593, doi:10.1126/science.1073198.

Weiss, H., Courty, M.-A., Wetterstrom, W., Guichard, F., Senior, L., Meadow, R., and Curnow, A., 1993, The genesis and collapse of third millennium North Mesopotamian civilization: Science, v. 261, p. 995-1004, doi:10.1126/science 261.5124.995.

Welsby, D.A., Macklin, M.G., and Woodward, J.C., 2002, Human responses to Holocene environmental changes in the northern Dongola reach of the Nile, in Friedman, R., ed., Egypt and Nubia: Gifts of the desert: London, British Museum Press, p. 28-41.

Williams, M.A.J., Adamson, D., Cock, B., and McEvedy, R., 2000, Late Quaternary environments in the White Nile region, Sudan: Global and Planetary Change, v. 26, p. 305-316, doi:10.1016 /S0921-8181(00)00047-3.

Woodward, J.C., Macklin, M.G., and Welsby, D.A., 2001, The Holocene fluvial sedimentary record and alluvial geoarchaeology in the Nile Valley of northern Sudan, in Maddy, D.M., et al., eds., River basin sediment systems: Archives of environmental change: Abingdon, UK, Balkema, p. $327-356$

Woodward, J.C., Macklin, M.G., Krom, M.D., and Williams, M.A.J., 2007, The Nile: Evolution, Quaternary river environments and material fluxes, in Gupta, A., ed., Large rivers: Geomorphology and management: Chichester, UK, John Wiley and Sons, p. 261-292.

Manuscript received 12 September 2012

Revised manuscript received 21 January 2013

Manuscript accepted 23 January 2013

Printed in USA 